\title{
Correction to: Invasion status and impacts of parthenium weed (Parthenium hysterophorus) in West-Central region of Bhutan
}

\author{
Ngawang Chhogyel (D) Lalit Kumar (D) Y Yadunath Bajgai $(\mathbb{D}$
}

Published online: 24 June 2021

(C) Springer Nature Switzerland AG 2021

Correction to: Biol Invasions

https://doi.org/10.1007/s10530-021-02534-3

Unfortunately, the original publication of the article contained the following errors.

The caption of the figures 3, 4 and 5 were published incorrectly and the correct captions are given in this correction.

The original article can be found online at https:// doi.org/10.1007/s10530-021-02534-3.

N. Chhogyel $(\bowtie) \cdot$ L. Kumar

School of Environmental and Rural Science, University of New England, Armidale, NSW 2351, Australia

e-mail: nchhogye@myune.edu.au;

cngawang11@gmail.com

L. Kumar

e-mail: 1kumar@une.edu.au

\section{N. Chhogyel}

Agriculture Research and Development Centre, Bajo, Department of Agriculture, Ministry of Agriculture and Forests, 14001 Wangdue Phodrang, Bhutan

Y. Bajgai

National Potato Program, Agriculture Research and

Development Centre, Yusipang, Department of

Agriculture, Ministry of Agriculture and Forests,

11001 Thimphu, Bhutan

e-mail: ybajgai@gmail.com
Fig. 3 Parthenium invasion of different land types in the three districts of Bhutan $(\mathrm{a}=$ Punakha, $\mathrm{b}=$ Tsirang, and $\mathrm{c}=$ Wangdue); Ranking scale: $1=$ least common, 2 = less common, 3 = somewhat common, 4 $=$ common, and $5=$ most common

Fig. 4 MaxEnt generated parthenium weed distribution model for the current climate based on the species presence-only data IPCC's bioclimatic variables

Fig. 5 Projected distribution of parthenium weed in the study site: (a) under the future, and (b) spatial changes under RCP2.6 and RCP8.5 emission scenarios of IPCC over 2070

In the introduction section, one reference after the sentence "The reasons for choosing these districts were: (1)...China and India, respectively" that read as "(NSSC and PPD, Ppd, 2011)" should read as "(NSSC and PPD 2011)"

The original article has been corrected

Publisher's Note Springer Nature remains neutral with regard to jurisdictional claims in published maps and institutional affiliations. 